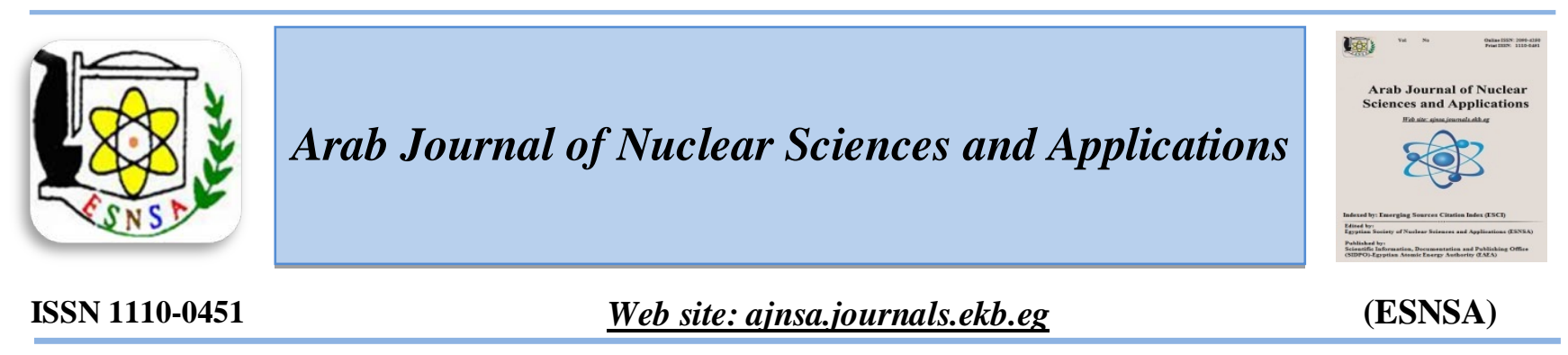

\title{
Radiological Risk Assessment in a Type of Complex Petroleum Refinery in Egypt
}

\author{
I. H. Saleh ${ }^{(1)}$, I. M. Othman ${ }^{(2)}$, Z.F. Ghatass ${ }^{(1)}$ and M.A. Metwally ${ }^{(2)}$ \\ ${ }^{1}$ Department of Environmental Studies, Institute of Graduate Studies and Research, Alexandria University, \\ Alexandria, Egypt \\ ${ }^{2}$ Middle East Oil Refinery, Midor, Amreya Free zone, Alexandria, Egypt
}

\begin{abstract}
Received $9^{\text {th }}$ Jan. 2018 The radiological and radioecological impacts associated with the uncontrolled release of TENORM in Accepted $3^{\text {rd }}$ June 2018 products and wastes released in the petroleum industry are of great concern. In this study, radiological risk assessment of TENORM in refined products, sludge, non-oil wastes and produced water are presented. Thirty-four statistically representative samples are divide into four groups, fourteen samples were refined petroleum products, nine samples were sludge waste, six samples were taken from used and fresh non-oil wastes and five samples were produced water. The activity concentrations of ${ }^{232} \mathrm{Th},{ }^{226} \mathrm{Ra}$ and ${ }^{40} \mathrm{~K}$ in all samples were measured by using gamma-ray spectrometry with high purity Germanium (HPGe) detector. The radium equivalent activity, external and internal hazard indices, gamma radiation absorbed doses rates and the annual effective dose were estimated. It was noticed that the maximum value of radium equivalent activity was found to be $308.773 \mathrm{~Bq} / \mathrm{kg}$ and observed in ceramic balls used for catalyst bed support and it was lower than its recommended upper limit, which is $370 \mathrm{~Bq} / \mathrm{kg}$. The external and internal hazard indices were indicated. It is recommended that for workers who are working in maintaining and repairing equipment must use safety tools to protect them from the dangers of inhaling radon gas. Generally, the overall results revealed that the radiation levels would not pose any radiological risk occupationally or for the ambient environment. The results obtained in this study are very important in terms of establishing indicators and standards for radiation protection in this type of crude oil refining technology.
\end{abstract}

\section{Introduction}

Keywords: Complex petroleum Refinery, Crude Oil, Radiation Doses, Risk Assessment, TENORM
The presence of naturally occurring radioactive material (NORM) has been recognized since early 1930s in petroleum reservoirs, in oil and gas production and in processing facilities. Oil scaling as a waste problem occurs either when production equipment is taken ashore for cleaning or as a part of the final waste handling during decommissioning of oil installations [1]. Naturally occurring radioactive materials (NORM) generally contain radionuclides found in nature, i.e., thorium, uranium, and their progeny. When NORM becomes concentrated in radionuclides due to human activity, one can speak about technologically enhanced naturally occurring radioactive materials (TENORM).

The petroleum waste (scale or sludge) are produced by two mechanisms: either incorporation or precipitation onto the production equipment such as pipelines, storage tank, pumps. etc. [2]. The precipitated TENORM wastes around walls of the petroleum pipes reduce their efficiency and then disposed and replaced periodically by new ones [3-4]. Both hazardous and non-hazardous solid wastes are generated during the refining process. Refinery wastes are typically in the form

Corresponding author: islam_mahmoud71@yahoo.com

DOI: 10.21608/ajnsa.2018.2581.1034

(C) Scientific Information, Documentation and Publishing Office (SIDPO)-EAEA 
of sludge, spent process catalysts, filter clay, and incinerator ash [5]. In addition, produced water contains enhanced naturally occurring radioactive materials (NORM) resulting from the ${ }^{232} \mathrm{Th}$ and ${ }^{238} \mathrm{U}$ series [6-12] this water is currently considered to be the largest volume of radioactive waste generated by the petroleum industry [8].

The present study aimed to evaluate the radiological impacts of TENORM during different petroleum refining processes, to obtain an extensive view to the radiological burden of the petroleum industry in Egypt. In addition, this study is intended to set-up working guidelines for both the workers in the companies and regulators with an understanding of the occupational and environmental risks from TENORMs generated in petroleum refining facilities in Egypt. Moreover, to establishing radiological data base for petroleum refining industry in Egypt generally.

The present study is concerned with the determination of activity concentrations of ${ }^{232} \mathrm{Th}$, ${ }^{226} \mathrm{Ra}$ and ${ }^{40} \mathrm{~K}$ content in the refined petroleum products, sludge generated during different stages of process, refinery non-oil wastes and produced water were collected from different locations in the refinery. The radium equivalent activity, radiation hazard indices, absorbed dose rate in air and annual effective dose were calculated.

\section{Experimental Work}

\section{Sampling and sample preparation}

Thirty-four samples were collected from different locations in a certain complex petroleum refinery, which is based on modern hydrocracking and delayed coker technologies selected to achieve extensive conversion of heavy material to desulphurized middle distillates while producing limited coke. Samples were divided into four groups, fourteen samples were taken from refined petroleum products, nine samples were from sludge, six samples were from generated refinery non-oil wastes, two of them were as fresh samples for comparing with other stored waste types, and five samples directly from produced water. Figure(1) shows locations of all studied samples during the refining process. Table (1) shows origin and description of all studied samples. The samples were weighted using by digital balance scale, packed in Marnelli beakers (polyethylene containers) of $1000 \mathrm{ml}$ capacity, closed tightly, sealed and stored for one month to establish secular equilibrium between the parent radionuclides and their respective daughters. The samples were subjected into gamma ray spectrometric analysis.

\section{Gamma-ray measurements}

The prepared samples were measured by a gamma ray spectrometer system in the radiation laboratory at the Department of Environmental Studies, Institute of Graduate Studies and Research (IGSR), Alexandria University. This detection system provides reliable tool for determination of uraium238 in sediment [13], as well as depleted uranium assessment in environment [14]. This spectrophotometric method was conventionally used in environmental wastes that refer to highly resolution of germanium detector and adequate efficiency of detector [15]. The measuring system consists of a p-type coaxial HPGe with an efficiency of $24.5 \%$ and a resolution of $1.7 \mathrm{keV}$ at $1.33 \mathrm{MeV}$. The gamma spectrum was recorded using a PC-based 8192 channel analyzer and processed by using the Genie-2000 software. The spectrometer was calibrated for energy by using a set of certified gamma radiation standard sources (137Cs, 60Co, 57Co and 241Am). The absolute detection efficiencies were calibrated for solid and liquid materials by using a certified standard source(152Eu) and soil reference materials prepared in geometrical shape and composition to simulate the investigated samples matrix [16]. The detector was shielded by a cylindrical lead castle of 0.1-m thickness with an internal wall made of copper. For internal quality control requirements, reference soil samples (MAPEP-13/14, Soil) were analyzed during the measurements to confirm the calibrations. Externally, the laboratory participates periodically in the proficiency testing (PT) program (MAPEP) for radiation measurements. The activity concentration of ${ }^{40} \mathrm{~K}$ was determined by using the $1460.8 \mathrm{keV}$ gamma line. The lines 295.2, 351.9, 609.3 and $1120.3 \mathrm{keV}$ were used for ${ }^{226} \mathrm{Ra}\left({ }^{238} \mathrm{U}\right.$ decay series) activity determination. The lines 338.4, 911.0 and $583.1 \mathrm{keV}$ were used to determine the activity of ${ }^{228} \mathrm{Ra}\left({ }^{232} \mathrm{Th}\right.$ decay series) [17]. The minimum detectable activity (MDA) was calculated for each radionuclide according to Eq. (1) [18]. The levels of MDA were calculated based on the counting conditions used for measuring the studied samples listed in Table (2). 


$$
M D A=\frac{\mathrm{LD}}{\mathrm{T} \times \mathrm{Eff}(\mathrm{E}) \times \mathrm{P} \gamma(\mathrm{E}) \times \mathrm{M}}
$$

Where, T, Eff. (E), $\mathbf{P} \boldsymbol{\gamma}(\mathbf{E})$ and $\mathbf{M}$ are the counting time, full-energy peak efficiency at photon energy (E) and emission probability specify the radionuclide at energy (E) and $\mathbf{M}$ is the Mass in $\mathrm{kg}$, respectively. Finally, $\mathbf{L}_{\mathbf{D}}$ is the detection limit, calculated by using the following equation,

$$
\mathbf{L}_{\mathbf{D}}=\mathbf{L}_{\mathbf{C}}+\mathbf{K}_{\mathbf{\sigma D}}
$$

Where, $\mathbf{L}_{\mathbf{C}}$ is the critical level, below which no signal can be detected, $\boldsymbol{\sigma D}$ is the standard deviation and $\mathbf{K}$ is the error probability.
The specific activity (A) of each radionuclide in $\mathrm{Bq} / \mathrm{kg}$ was calculated according to the following Eq. (3) [19].

$$
A(B q / k g)=\frac{\text { net cps }(\mathrm{E})}{\varepsilon(\mathrm{E}) \times \mathrm{m} \times P_{\gamma}(\mathrm{E})}
$$

Where, net cps, is the net count per second at energy (E), $\varepsilon$, is the absolute detection efficiency of $\gamma$-ray at energy (E), $m$, is the mass of measured sample and $\mathrm{P} \gamma(\mathrm{E})$, is the probability of gamma transition per disintegration at energy $(\mathrm{E})$.

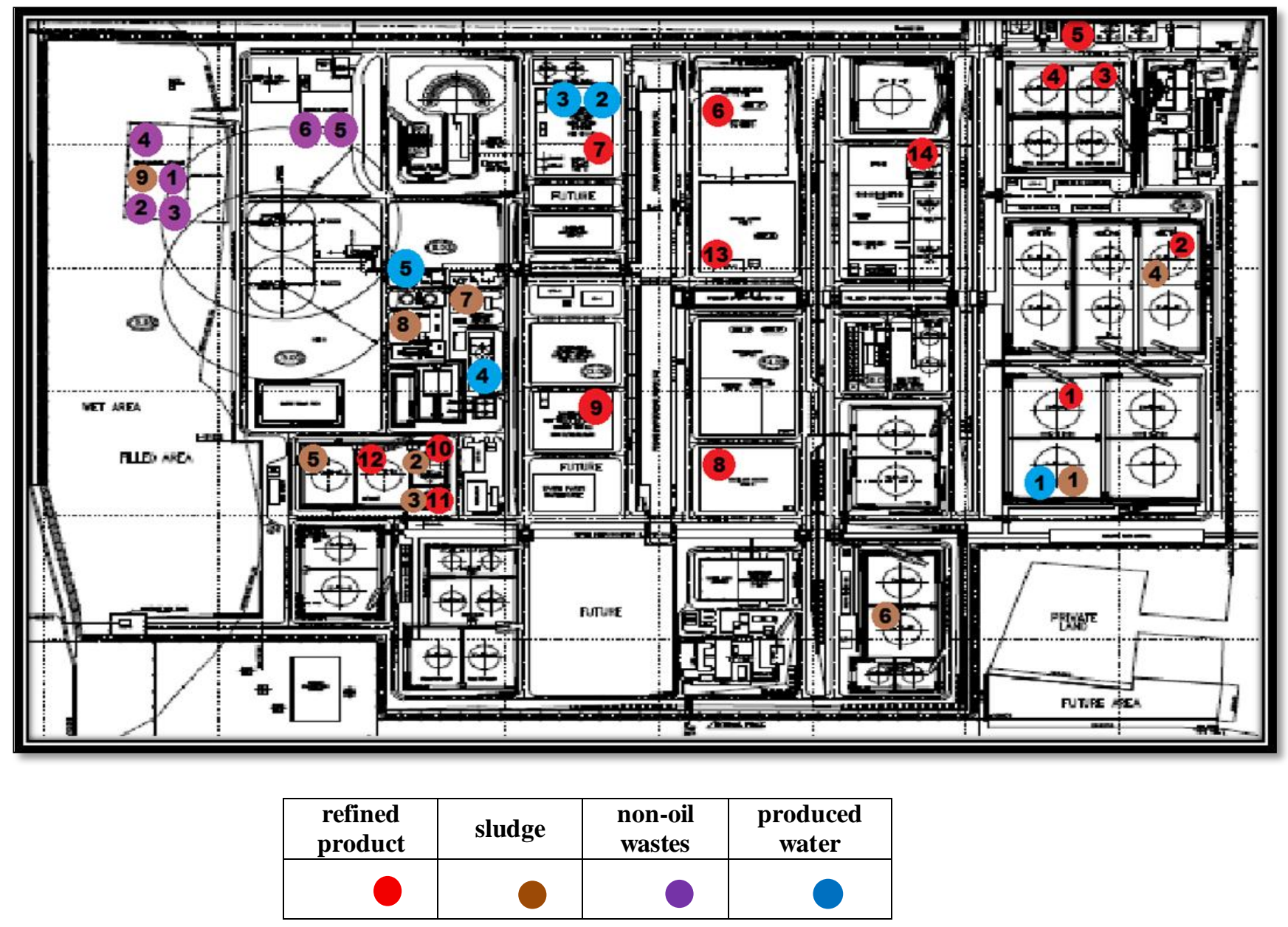

Figure (1) Locations of all studied samples during the refining process 
Saleh I. H. et al.

Table (1) Origin and description of all studied samples

\begin{tabular}{|c|c|c|c|}
\hline \multicolumn{2}{|r|}{ Sample Info. } & \multirow[b]{2}{*}{ Sample origin and description } & \multirow[b]{2}{*}{ Sample phase } \\
\hline $\begin{array}{c}\text { Sample } \\
\text { Code }\end{array}$ & Sample Name & & \\
\hline \multicolumn{2}{|c|}{ Refined petroleum products } & & \\
\hline $\mathbf{P}-1$ & Crude oil & Storage tanks area $(\mathrm{TK} 01) *$, received to refinery by SOMED & Liquid \\
\hline $\mathbf{P}-2$ & Diesel oil & Storage Tanks Area (TK37), final product & Liquid \\
\hline $\mathbf{P}-\mathbf{3}$ & Kerosene Product & Storage Tanks Area(TK19), feed to Kerosene treating unit & Liquid \\
\hline $\mathbf{P}-4$ & Jet oil (final Product) & Storage Tanks Area (TK33), Final Product & Liquid \\
\hline P-5 & Gasoline & Storage Tanks Area (TK30), Final Product & Liquid \\
\hline P-6 & Green Coke & Coker Unit (11), Final Product & Solid \\
\hline $\mathbf{P}-7$ & Sulfur & Sulfur Recovery Unit (56), Final Product from Sulfur Rec. unit & Solid \\
\hline P-8 & S. R. Kerosene & Crude Distillation Unit (01), feed to Kerosene treating unit & Liquid \\
\hline P-9 & Kerosene (final Product) & Kerosene Treatment Unit (06), Final Product & Liquid \\
\hline P-10 & Heavy slop oil & Storage Tanks Area (TK07), feed to Hydro - Cracker unit & Liquid \\
\hline $\mathbf{P - 1 1}$ & Light slop oil & Storage Tanks Area (TK06), fraction from Distillation unit & Liquid \\
\hline P-12 & Vacuum gasoil (VGO) & Storage Tanks Area (TK40), feed to Hydro - cracker unit & Liquid \\
\hline $\mathbf{P}-\mathbf{1 3}$ & Vacuum residue(VR) cold & Coker Unit (11), from VDU Unit and feed to Coker unit & Liquid \\
\hline $\mathbf{P}-14$ & Unconverted oil & Utility Area Units - TK01 (Unit 44), fuel oil to ignite Heaters & Liquid \\
\hline \multicolumn{2}{|r|}{ Sludge } & & \\
\hline S-1 & Crude oil Sludge & Storage Tanks Area (TK04), received to refinery by SOMED & Liquid \\
\hline $\mathrm{S}-2$ & Heavy slop oil Sludge & Storage Tanks Area (TK07), feed to Hydro- Cracker unit & Liquid \\
\hline S-3 & Light slop oil Sludge & Storage Tanks Area (TK06), Sludge fraction from distillation & Liquid \\
\hline S-4 & Diesel Sludge & Storage Tanks Area (TK37), Sludge in final product tank & Liquid \\
\hline S-5 & Vacuum gasoil Sludge & Storage Tanks Area (TK41), feed to Hydro - Cracker unit & Liquid \\
\hline S-6 & Gasoline Sludge & Storage Tanks Area (TK29), Sludge with Final Product & Liquid \\
\hline S-7 & Oily Sludge to Coker unit & Waste Water Treatment units, Sludge from refinery stations & Liquid \\
\hline S-8 & Bio - Sludge & Waste Water Treatment units, from Biological water treatment & Liquid \\
\hline S-9 & Combine Stored Sludge & Waste Area (Barrels), from different sources of refinery & Liquid \\
\hline \multicolumn{2}{|r|}{ Refinery non-oil wastes } & & \\
\hline W-1 & Clay filter (used) & Waste Area (Paged), during routinely change over & Solid \\
\hline $\mathrm{W}-2$ & Thermal Insulation (used) & Waste Area (Paged), oily cont. during cleaning activates & Solid \\
\hline W-3 & Hydrocracker Catalyst (used) & Waste Area (Barrels), as a Waste & Solid \\
\hline W-4 & Ceramic Balls (used) & Waste Area (Paged), Waste used for Catalyst supporting & Solid \\
\hline W-5 & Clay filter (fresh) & Chemicals Storage, fresh from source ready for reloading & Solid \\
\hline W-6 & Catalyst (fresh) & Chemicals Storage, fresh from source ready for reloading & Solid \\
\hline \multicolumn{2}{|r|}{ Produced water } & & \\
\hline Wa-1 & Water associated crude oil & Storage Tanks Area (TK02), with crude from well (oil field) & Liquid \\
\hline Wa-2 & Refinery Sour Water & Feed to Sour Water Unit (15), after oil separation to treating & Liquid \\
\hline Wa-3 & Stripped water & Outlet from Sour Water Unit (15), clear water for reusing & Liquid \\
\hline Wa-4 & Oily water & Waste Water Treatment Units & Liquid \\
\hline Wa-5 & Treated water & Waste Water Treatment Units (Bas. 14) Discharged to Lake & Liquid \\
\hline
\end{tabular}

*: Tank 


\begin{tabular}{ccc}
\hline \multicolumn{2}{|c}{$\begin{array}{c}\text { Table (2) Minimum detectable activities (MDA) for the } \\
\text { detected radionuclides at 10 hr. counting time }\end{array}$} \\
\hline Radionuclide & $\begin{array}{c}\text { Gamma } \\
\text { energy (Kev) }\end{array}$ & $\begin{array}{c}\text { MDA } \\
\text { (Bq/kg) }\end{array}$ \\
\hline${ }^{228} \mathbf{A c}$ & 911.0 & 0.02 \\
${ }^{137} \mathbf{C s}$ & 661.7 & 0.02 \\
${ }^{40} \mathbf{K}$ & 1460.8 & 0.20 \\
${ }^{214} \mathbf{P b}$ & 351.9 & 0.06 \\
${ }^{214} \mathbf{B i}$ & 609.3 & 0.06 \\
${ }^{226} \mathbf{R a}$ & 186.2 & 0.20 \\
\hline
\end{tabular}

\section{Calculations of Radiological Effect}

Radium equivalent index ( $R a-e q$ )

The radium equivalent activity (Ra-eq) in $\mathrm{Bq} / \mathrm{kg}$ was introduced to define uniformity in respect to radiation exposure [20-21]. Ra-eq is defined as an estimation of radiation of $370 \mathrm{~Bq} / \mathrm{kg}$ of ${ }^{226} \mathrm{Ra}, 259$ $\mathrm{Bq} / \mathrm{kg}$ of ${ }^{232} \mathrm{Th}$ and $4810 \mathrm{~Bq} / \mathrm{kg}$ of ${ }^{40} \mathrm{~K}$ in a material that produce the same gamma ray dose rate. The (Ra-eq) in $\mathrm{Bq} / \mathrm{kg}$ was calculated using the following Eq. (4) [20].

$$
\mathrm{R}_{\mathrm{a}-\mathrm{eq}}=\mathrm{A}_{\mathrm{Ra}}+1.43 \mathrm{~A}_{\mathrm{Th}}+0.077 \mathrm{~A}_{\mathrm{K}}
$$

Where, $A_{R a}, A_{T h}$ and $A_{K}$ are the activity concentrations in $\mathrm{Bq} / \mathrm{kg}$ of ${ }^{226} \mathrm{Ra},{ }^{232} \mathrm{Th}$ and ${ }^{40} \mathrm{~K}$ respectively.

\section{External and internal hazard indices}

A widely used hazard index called the external hazard index $\mathrm{H}_{\mathrm{ex}}$ is defined as follows in order to limit the external gamma radiation to $1.5 \mathrm{mSv} / \mathrm{y}$ [22]:

$$
\mathrm{H}_{\mathrm{ex}}=\mathrm{A}_{\mathrm{Ra}} / 370+\mathrm{A}_{\mathrm{Th}} / 239+\mathrm{A}_{\mathrm{K}} / 4810
$$

Where, $A_{\text {Ra }}, A_{T h}$ and $A_{K}$ as in Eq. (4).

The model of the external hazard index $\left(\mathrm{H}_{\mathrm{ex}}\right)$ puts an upper limit to the external gamma radiation dose from NORMs to unity, which corresponds to a radium equivalent activity of $370 \mathrm{~Bq} / \mathrm{kg}[18,31]$. In addition to external hazard index, radon and its short-lived products are also hazardous to the respiratory organs. The internal exposure to radon and its daughter products was quantified by the internal hazard index $\left(\mathrm{H}_{\text {in }}\right)$, which is given by $\mathrm{Eq}$. (6) [20]:

$$
\mathrm{H}_{\mathrm{in}}=\mathrm{A}_{\mathrm{Ra}} / 185+\mathrm{A}_{\mathrm{Th}} / 259+\mathrm{A}_{\mathrm{K}} / 4810
$$

The values of the indices $\mathrm{H}_{\mathrm{ex}}$ and $\mathrm{H}_{\mathrm{in}}$ must be less than unity for the internal radiation hazard to be insignificant.

\section{External absorbed dose rate}

The absorbed dose rates (D) due to gamma radiations in air at $1 \mathrm{~m}$ above the ground surface for the uniform distribution of the naturally occurring radionuclides $\left({ }^{226} \mathrm{Ra},{ }^{232} \mathrm{Th}\right.$ and $\left.{ }^{40} \mathrm{~K}\right)$ were calculated based on guidelines provided by [22] according to the following Eq. (7) [22]:

$$
\mathrm{D}(\mathrm{nGy} / \mathrm{h})=0.462 \mathrm{~A}_{\mathrm{Ra}}+0.621 \mathrm{~A}_{\mathrm{Th}}+0.0417 \mathrm{~A}_{\mathrm{K}}(7)
$$

Where, $A_{R a}, A_{T h}$ and $A_{K}$ as in Eq. (4).

It is recommended that the acceptable total absorbed dose rate by the workers in areas containing gamma radiations from ${ }^{238} \mathrm{U}$ and ${ }^{232} \mathrm{Th}$ series and their respective decay progenies, as well as ${ }^{40} \mathrm{~K}$ must not exceed $55 \mathrm{nGy} / \mathrm{h}$ [22].

\section{Annual Effective Dose}

The external dose rate (D) due to gamma rays of ${ }^{226} \mathrm{Ra},{ }^{232} \mathrm{Th}$ and ${ }^{40} \mathrm{~K}$ in TENORM was converted to annual effective dose (AED) by using the following Eq. (8) [22]:

$\operatorname{AED}\left(\mathrm{mSv} \cdot \mathrm{yr}^{-1}\right)=\mathrm{D}\left(\mathrm{nGy} \cdot \mathrm{h}^{-1}\right) \times 8760\left(\mathrm{~h} \cdot \mathrm{yr}^{-1}\right) \mathrm{xOxCx} 10^{-3}$

Where, $\mathrm{O}$ is the occupancy factor and taken to be 0.285 in accordance with the company's working shifts and $\mathrm{C}$ is the absorbed to effective dose conversion factor, which is (0.7 Sv/Gy) [22].

\section{Results and Discussion}

Activity concentration of radionuclides in refined petroleum products

Assuming the levels of NORMs are of homogenized distribution in investigated materials, the radioactivity concentrations for naturally occurring radionuclides in $(\mathrm{Bq} / \mathrm{kg})$ of ${ }^{226} \mathrm{Ra},{ }^{228} \mathrm{Ra}$ and ${ }^{40} \mathrm{~K}$ in refined product samples were listed in Table (3).

The results showed that the concentration of ${ }^{226} \mathrm{Ra}$ ranges from $<0.2 \mathrm{~Bq} / \mathrm{kg}$ (MDA) in samples diesel oil ( $\mathrm{P}-2)$, jet oil (final product) $(\mathrm{P}-4)$, gasoline $(\mathrm{P}-$ 5) and sulfur (P-7) to $46.78 \pm 0.076 \mathrm{~Bq} / \mathrm{kg}$ in vacuum residue sample (VR) (P-13). It is clear that most of observed level were below the worldwide average $(40 \mathrm{~Bq} / \mathrm{kg})[9,23]$ except the vacuum residue (VR) (P-13) sample. The obtained average value of ${ }^{226} \mathrm{Ra}$ in this group of samples is 9.492 $\mathrm{Bq} / \mathrm{kg}$. 
Saleh I. H. et al.

Table (3) Radioactivity concentrations in refined petroleum product samples (Bq/kg)

\begin{tabular}{ccccc}
\hline $\begin{array}{c}\text { Sample } \\
\text { Code }\end{array}$ & Sample Name & ${ }^{226} \mathbf{R a}$ & ${ }^{228} \mathbf{R a}$ & ${ }^{40} \mathbf{K}$ \\
\hline P-1 & Crude oil & $3.02 \pm 0.029$ & $<0.02$ & $<0.2$ \\
P-2 & Diesel oil & $<0.2$ & $<0.02$ & $6.06 \pm 0.041$ \\
P-3 & Kerosene Product & $9.92 \pm 0.032$ & $<0.02$ & $8.29 \pm 0.029$ \\
P-4 & Jet oil (final Product) & $<0.2$ & $<0.02$ & $<0.2$ \\
P-5 & Gasoline & $<0.2$ & $8.31 \pm 0.039$ & $16.79 \pm 0.056$ \\
P-6 & Green Coke & $5.46 \pm 0.032$ & $<0.02$ & $5.33 \pm 0.031$ \\
P-7 & Sulfur & $<0.2$ & $<0.02$ & $2.31 \pm 0.021$ \\
P-8 & S. R. Kerosene & $6.82 \pm 0.025$ & $<0.02$ & $5.98 \pm 0.023$ \\
P-9 & Kerosene (final Product) & $20.69 \pm 0.048$ & $<0.02$ & $15.33 \pm 0.041$ \\
P-10 & Heavy slop oil & $21.67 \pm 0.078$ & $<0.02$ & $17.80 \pm 0.07$ \\
P-11 & Light slop oil & $9.86 \pm 0.052$ & $4.40 \pm 0.035$ & $13.31 \pm 0.061$ \\
P-12 & Vacuum gasoil (VGO) & $4.61 \pm 0.023$ & $10.50 \pm 0.035$ & $6.52 \pm 0.027$ \\
P-13 & Vacuum residue (VR) & $46.78 \pm 0.076$ & $<0.02$ & $5.52 \pm 0.026$ \\
P-14 & Unconverted oil & $4.11 \pm 0.022$ & $<0.02$ & $3.35 \pm 0.019$ \\
\hline
\end{tabular}

Results of ${ }^{228} \mathrm{Ra}$ revealed that its levels are $<0.02$ $\mathrm{Bq} / \mathrm{kg}$ (MDA) except the light slop oil (P-11), gasoline $(\mathrm{P}-5)$ and vacuum gasoline (VGO) $(\mathrm{P}-12)$ their values are $4.40 \pm 0.035,8.31 \pm 0.039$ and $10.50 \pm 0.035 \mathrm{~Bq} / \mathrm{kg}$ respectively. The average level of ${ }^{228} \mathrm{Ra}$ in this group which represents the ${ }^{232} \mathrm{Th}$ series $(1.657 \mathrm{~Bq} / \mathrm{kg})$ is lower than worldwide average (20 Bq/kg). [9, 23].

The values of ${ }^{40} \mathrm{~K}$ ranged from $<0.2 \mathrm{~Bq} / \mathrm{kg}$ (MDA) in (P-1) and (P-4) which are crude and jet oil respectively to $17.80 \pm 0.07 \mathrm{~Bq} / \mathrm{kg}$ in heavy slop oil $(\mathrm{P}-10)$. The overall average value was 7.613 $\mathrm{Bq} / \mathrm{kg}$.

Activity concentration of radionuclides in sludge The activity concentrations for sludge samples were listed in Table (4)

The observed activity levels of ${ }^{226} \mathrm{Ra}$ in sludge samples ranged from $<0.2 \mathrm{~Bq} / \mathrm{kg}$ (MDA) in heavy slop oil sludge (S-2) to $44.30 \pm 0.111 \mathrm{~Bq} / \mathrm{kg}$ in biosludge (S-8) with an overall average value of $20.686 \mathrm{~Bq} / \mathrm{kg}$.
The ${ }^{228} \mathrm{Ra}$ concentration ranged from $<0.02 \mathrm{~Bq} / \mathrm{kg}$ (MDA) observed in heavy slop oil sludge (S-2), light slop oil sludge (S-3), diesel sludge (S-4), vacuum gasoil (VGO) sludge (S-5) and oily sludge (S-7) to $43.89 \pm 0.110 \mathrm{~Bq} / \mathrm{kg}$ in sample bio - sludge (S-8). The overall average value was $7.953 \mathrm{~Bq} / \mathrm{kg}$.

The value of ${ }^{40} \mathrm{~K}$ ranged from $<0.2 \mathrm{~Bq} / \mathrm{kg}$ (MDA) to $19.44 \pm 0.073 \mathrm{~Bq} / \mathrm{kg}$ with an average value of $9.562 \mathrm{~Bq} / \mathrm{kg}$. The lowest value was found in vacuum gas oil (VGO) sludge (S-5), while the highest value was detected in heavy slop oil sludge (S-2).

Activity concentration of radionuclides in refinery non-oil wastes

The levels of radioactivity concentration in non-oil waste samples were listed in Table (5) 
Table (4) Radioactivity concentrations in sludge samples (Bq/kg)

\begin{tabular}{ccccc}
\hline $\begin{array}{c}\text { Sample } \\
\text { Code }\end{array}$ & Sample Name & ${ }^{226} \mathbf{R a}$ & ${ }^{228} \mathbf{R a}$ & ${ }^{40} \mathbf{K}$ \\
\hline S-1 & Crude Sludge & $33.68 \pm 0.056$ & $24.79 \pm 0.048$ & $9.85 \pm 0.03$ \\
S-2 & Heavy slop oil Sludge & $<0.2$ & $<0.02$ & $19.44 \pm 0.073$ \\
S-3 & Light slop oil Sludge & $22.11 \pm 0.078$ & $<0.02$ & $9.18 \pm 0.050$ \\
S-4 & Diesel Sludge & $1.84 \pm 0.022$ & $<0.02$ & $9.35 \pm 0.052$ \\
S-5 & Vacuum gasoil (VGO) Sludge & $33.13 \pm 0.110$ & $<0.02$ & $<0.2$ \\
S-6 & Gasoline Sludge & $4.58 \pm 0.021$ & $0.92 \pm 0.008$ & $7.71 \pm 0.027$ \\
S-7 & Oily Sludge to Coker unit & $41.07 \pm 0.106$ & $<0.02$ & $3.73 \pm 0.032$ \\
S-8 & Bio - Sludge & $44.30 \pm 0.111$ & $43.89 \pm 0.110$ & $12.06 \pm 0.058$ \\
S-9 & Combine Stored Sludge & $5.47 \pm 0.023$ & $1.98 \pm 0.014$ & $14.74 \pm 0.037$ \\
\hline
\end{tabular}

Table (5) Radioactivity concentrations in refinery non-oil waste samples (Bq/kg)

\begin{tabular}{ccccc}
\hline $\begin{array}{c}\text { Sample } \\
\text { Code }\end{array}$ & Sample Name & ${ }^{226} \mathbf{R a}$ & ${ }^{228} \mathbf{R a}$ & ${ }^{40} \mathbf{K}$ \\
\hline W-1 & Clay filter (used) & $140.74 \pm 0.177$ & $42.24 \pm 0.097$ & $313.57 \pm 0.264$ \\
W-2 & Thermal Insulation (used) & $78.27 \pm 0.120$ & $48.34 \pm 0.095$ & $279.38 \pm 0.227$ \\
W-3 & Hydrocracker Catalyst (used) & $7.07 \pm 0.036$ & $<0.02$ & $7.17 \pm 0.036$ \\
W-4 & Ceramic Balls (used) & $78.32 \pm 0.147$ & $92.01 \pm 0.160$ & $1284.15 \pm 0.597$ \\
W-5 & Clay filter (fresh) & $119.75 \pm 0.163$ & $56.55 \pm 0.122$ & $373.22 \pm 0.288$ \\
W-6 & Catalyst (fresh) & $<0.2$ & $<0.02$ & $<0.2$ \\
\hline
\end{tabular}

${ }^{226} \mathrm{Ra}$ activity concentration in 6 non-oil waste types in the refinery are $<0.2 \mathrm{~Bq} / \mathrm{kg}$ (MDA) in fresh catalyst (W-6) to $140.74 \pm 0.177 \mathrm{~Bq} / \mathrm{kg}$ in used clay filter (used) (W-1) with an average value of $70.691 \mathrm{~Bq} / \mathrm{kg}$.

${ }^{228} \mathrm{Ra}$ concentration levels ranged from $<0.02$ $\mathrm{Bq} / \mathrm{kg}$ (MDA) to $92.01 \pm 0.160 \mathrm{~Bq} / \mathrm{kg}$ with an average value of $39.586 \mathrm{~Bq} / \mathrm{kg}$. The lowest value was found in (W-3) and (W-6) which are hydrocracker catalyst and fresh catalyst, respectively. On other hand, the highest value was found in ceramic balls (W-4).

The activity concentration of ${ }^{40} \mathrm{~K}$ ranged from $<0.2$ $\mathrm{Bq} / \mathrm{kg}$ (MDA) to $1284.15 \pm 0.597 \mathrm{~Bq} / \mathrm{kg}$ with an average value of $376.248 \mathrm{~Bq} / \mathrm{kg}$. The lowest value was found in fresh catalyst (W-6), while the highest value was detected in ceramic balls (W-4).

Activity concentrations of natural radionuclides $\left({ }^{226} \mathrm{Ra}\right.$, ${ }^{228} \mathrm{Ra}$, and $\left.{ }^{40} \mathrm{~K}\right)$ in used ceramic balls (W-4) were higher than other refinery non-oil wastes. It is well known that, ceramics are composed of raw materials that include atomized glaze, pigments and micronized zirconium silicate that have elevated levels of natural radioactivity [24-25]. In addition, thermal insulation materials are made of ceramic fibers that contains $\mathrm{ZrO}_{2}$ (zirconium dioxide) and alumina silicate and this may the causes of increasing of these levels [26]. 
The high levels of radionuclides were observed in both fresh and used clay, filters might be attributed to its original compositions [27]. That was confirmed by observed insignificant difference between the levels in fresh and used filters. Moreover, presence of potassium which is widely distributed in nature and due to presence of fossils and mammals (rich with potassium). Potassium concentrations vary from about $0.1 \%$ for limestone, through $1 \%$ for sandstones to as much as $3.5 \%$ for some granite [28-29]. Therefore, it exists in clays with highly concentrations

Activity concentration of radionuclides in produced water

The activity concentrations in produced water samples were listed in Table (6). The results show that ${ }^{226} \mathrm{Ra}$ activity concentration ranges from 1.07 $\pm 0.017 \mathrm{~Bq} / \mathrm{L}$ in treated water (Wa-5) to 34.15 $\pm 0.049 \mathrm{~Bq} / \mathrm{L}$ in oily water (Wa-4) with an overall average value of $15.916 \mathrm{~Bq} / \mathrm{L}$.

${ }^{228} \mathrm{Ra}$ concentration ranges from $<0.02 \mathrm{~Bq} / \mathrm{L}$ (MDA) to $13.26 \pm 0.029 \mathrm{~Bq} / \mathrm{L}$ with an average value of $4.342 \mathrm{~Bq} / \mathrm{L}$. The lowest value was found in refinery sour water (Wa-2) and treated water (Wa-5), while the highest value was found in water-associated crude oil (Wa-1).
The activity concentration of ${ }^{40} \mathrm{~K}$ ranged from 3.60 \pm 0.031 to $15.37 \pm 0.031 \mathrm{~Bq} / \mathrm{L}$ with an average value of $7.366 \mathrm{~Bq} / \mathrm{L}$. The lowest value was found in treated water (Wa-5), while the highest value was found in water-associated crude oil (Wa-1). It is well known that radium salts are one of soluble radiochemical under certain physical and chemical conditions therefore, it leaches from the petroleum reservoir rocks to the formation water in oil reservoir) $[10,30]$. So, they may be attributed to increase concentrations of radium in produced water.

\section{Radiological Risk Assessment for Study Samples \\ Radium equivalent index}

The radium equivalent activity (Ra-eq) for all studied samples was calculated using Eq. (4) and results were illustrated in Figure(2) The average calculated value of Ra-eq was $44.79 \mathrm{~Bq} / \mathrm{kg}$. Values ranged from under estimated level in Jet oil (P-4) and fresh catalyst (W-6) to $308.77 \mathrm{~Bq} / \mathrm{kg}$ in ceramic balls (W-4). It is clear that all values of Ra-eq for all studied samples are lower than the recommended maximum value $370.0 \mathrm{~Bq} / \mathrm{kg}$. [20, 25]

Table (6) Radioactivity concentrations in produced water samples $(\mathrm{Bq} / \mathrm{L})$

\begin{tabular}{ccccc}
\hline $\begin{array}{l}\text { Sample } \\
\text { Code }\end{array}$ & Sample Name & ${ }^{226} \mathbf{R a}$ & ${ }^{228} \mathbf{R a}$ & ${ }^{40} \mathbf{K}$ \\
\hline Wa-1 & Water associated crude oil & $9.35 \pm 0.024$ & $13.26 \pm 0.029$ & $15.37 \pm 0.031$ \\
Wa-2 & Refinery Sour water & $16.72 \pm 0.039$ & $<0.02$ & $8.27 \pm 0.027$ \\
Wa-3 & Stripped water & $18.29 \pm 0.071$ & $4.02 \pm 0.033$ & $5.65 \pm 0.038$ \\
Wa-4 & Oily water & $34.15 \pm 0.049$ & $4.43 \pm 0.018$ & $3.94 \pm 0.016$ \\
Wa-5 & Treated water & $1.07 \pm 0.017$ & $<0.02$ & $3.60 \pm 0.031$ \\
\hline
\end{tabular}




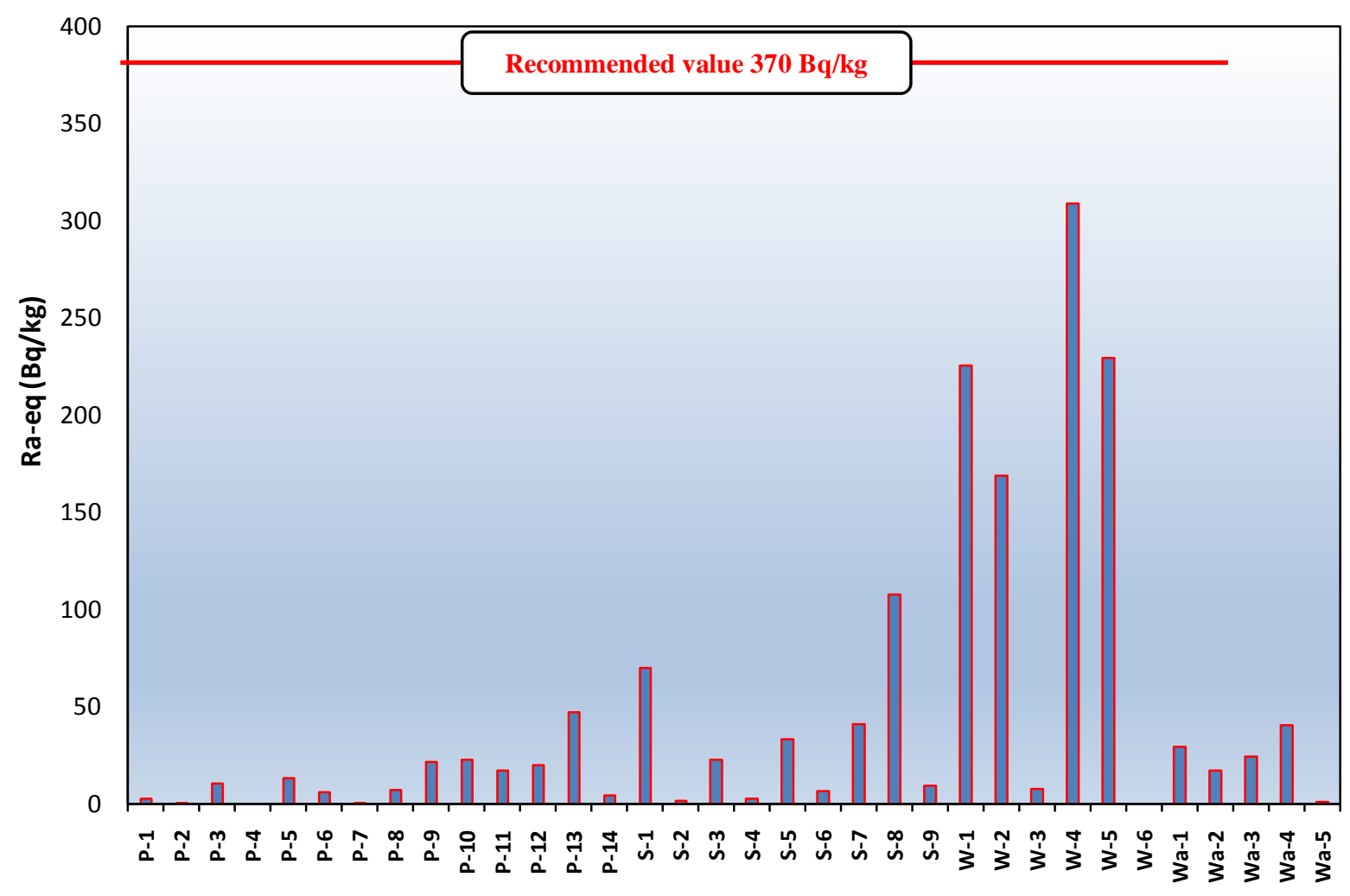

Figure (2) The calculated radium equivalent (Bq/kg) for the studied samples

\section{External absorbed dose rate}

Radiation exposure from oil and gas NORM can occur from seven environmental pathways: radon inhalation, external gamma exposure, groundwater ingestion, surface-water ingestion, dust inhalation, food ingestion, and skin beta exposure [7]. The pathway of greatest concern in petroleum industries workers is external gamma exposure, dust inhalation and skin beta exposure. External exposure source occurs when, first the concentration of NORM inside equipment is high enough that gamma rays penetrate the equipment walls and second contaminated scale and sludge are removed from the equipment. The total absorbed dose rate due to gamma emissions was estimated from Eq. (7) and the values obtained are illustrated in Figure(3) The overall average of absorbed dose in all studied samples was 20.725 $\mathrm{nGy} / \mathrm{h}$. The lowest values of the total absorbed gamma-dose rate were under estimated values recorded in jet oil (final Product) (P-4) and Catalyst (fresh) (W-6), while the highest one was
146.871 nGy/h in ceramic balls (W-4). The UNSCEAR report recommended that the acceptable total absorbed dose rate to workers in areas with gamma-radiations from ${ }^{238} \mathrm{U}$ and ${ }^{232} \mathrm{Th}$ series and their respective progenies, in addition to ${ }^{40} \mathrm{~K}$ must not exceed $55 \mathrm{nGy} / \mathrm{h}$ [33]. It is clear that the calculated total absorbed dose rates for some waste samples as clay filter (used) (W-1), thermal insulation (used) (W-2), ceramic balls (used) (W4) and clay filter (fresh) (W-5) were higher than the recommended acceptable dose level.

\section{Annual effective dose}

The annual effective dose for all studied samples was calculated using Eq. (8). Figure(4) illustrates the annual effective dose obtained for all sampling sites. It is clear that values of annual effective doses for all studied samples were lower than the worldwide-recommended value $(0.07 \mathrm{mSv} / \mathrm{y})$. Ceramic balls (W-4) from non-oil wastes group are the only waste type that exceeds the worldwiderecommended value. 


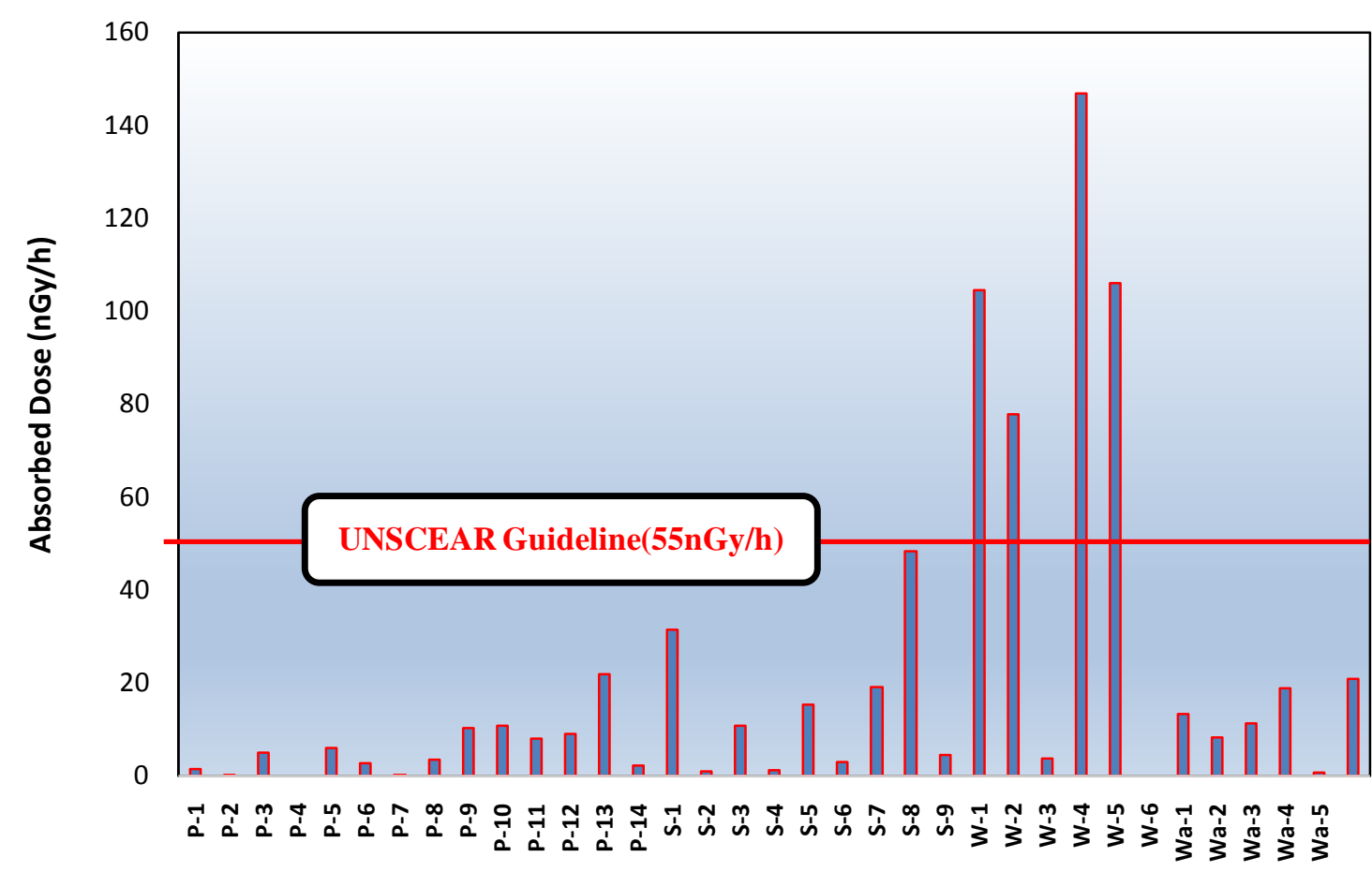

Figure (3) The absorbed dose rate (nGy/h) for all studied samples

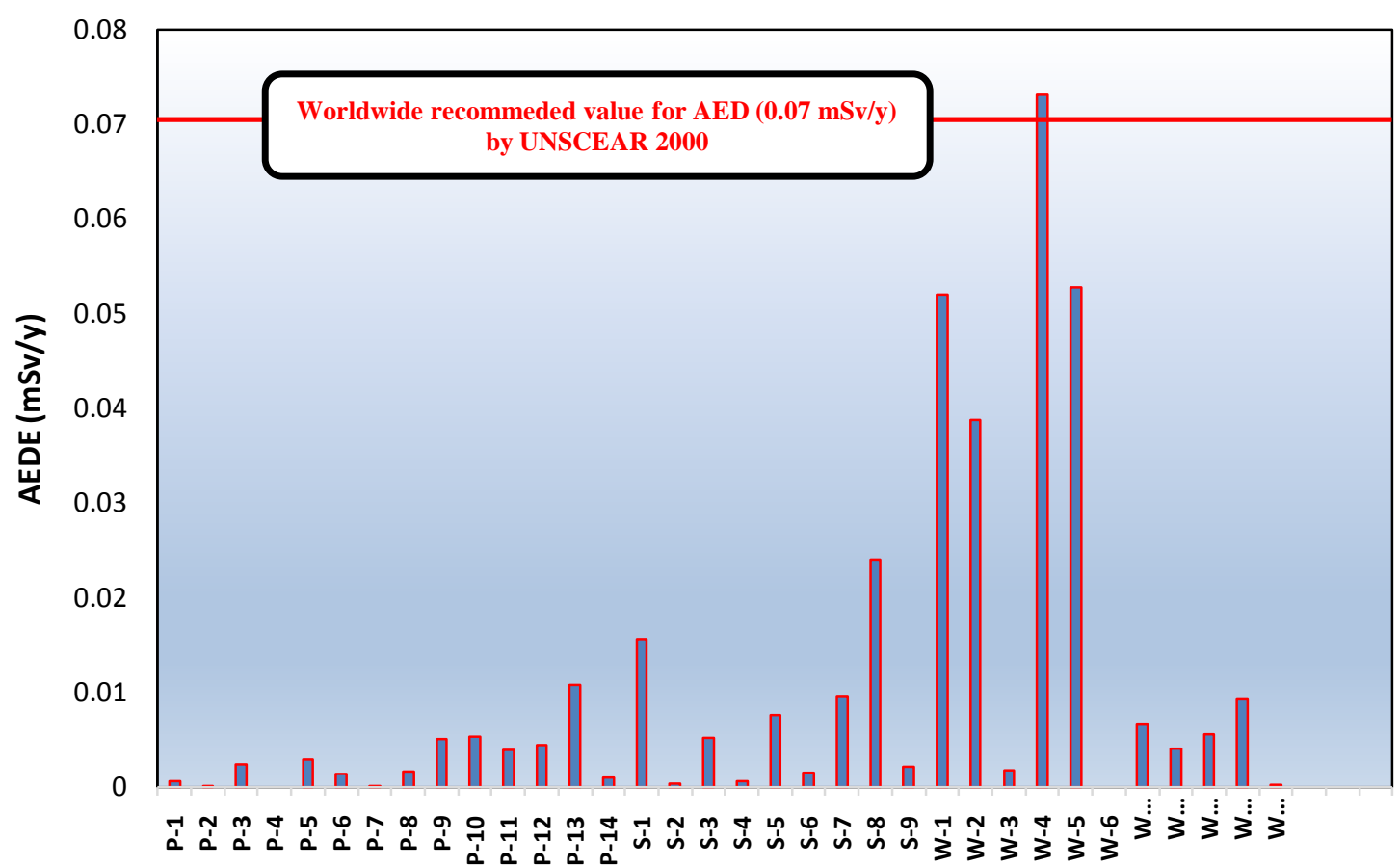

Figure (4) The annual effective dose equivalent rate in sampling sites

\section{Internal and external hazard indices}

Table (7) Presents the external hazard index $\left(\mathrm{H}_{\mathrm{ex}}\right)$ and internal hazard index $\left(\mathrm{H}_{\text {in }}\right)$. It is obvious that

their values are lower than unity [32], except $\mathrm{H}_{\text {in }}$ in ceramic balls (W-4) that exceed unity to be 1.045. 
Table (7) the external hazard index $\left(\mathrm{H}_{\mathrm{ex}}\right)$ and internal hazard index $\left(\mathrm{H}_{\mathrm{in}}\right)$ for all studied samples

\begin{tabular}{|c|c|c|c|}
\hline $\begin{array}{l}\text { Sample } \\
\text { Code }\end{array}$ & Sample name & $\mathbf{H}_{\mathrm{ex}}$ & $\mathbf{H}_{\mathrm{in}}$ \\
\hline P-1 & Crude oil & 0.008 & 0.016 \\
\hline P-2 & Diesel oil & 0.001 & 0.001 \\
\hline $\mathbf{P}-\mathbf{3}$ & Kerosene & 0.028 & 0.055 \\
\hline P-4 & Jet oil & $\mathrm{UE}^{*}$ & UE \\
\hline P-5 & Gasoline & 0.038 & 0.035 \\
\hline P-6 & Green Coke & 0.015 & 0.03 \\
\hline P-7 & Sulfur & 0.0004 & 0.0004 \\
\hline P-8 & S. R. Kerosene & 0.019 & 0.038 \\
\hline P-9 & Kerosene & 0.059 & 0.115 \\
\hline P-10 & Heavy slop oil & 0.062 & 0.12 \\
\hline P-11 & Light slop oil & 0.047 & 0.073 \\
\hline P-12 & Vacuum gasoil & 0.057 & 0.066 \\
\hline P-13 & Vacuum residue (VR) & 0.127 & 0.253 \\
\hline P-14 & Unconverted oil & 0.011 & 0.022 \\
\hline S-1 & Crude Sludge & 0.196 & 0.279 \\
\hline S-2 & Heavy slop oil Sludge & 0.004 & 0.004 \\
\hline S-3 & Light slop oil Sludge & 0.061 & 0.121 \\
\hline S-4 & Diesel Sludge & 0.006 & 0.011 \\
\hline S-5 & Vacuum gasoil (VGO) Sludge & 0.089 & 0.179 \\
\hline S-6 & Gasoline Sludge & 0.017 & 0.029 \\
\hline S-7 & Oily Sludge & 0.111 & 0.222 \\
\hline S-8 & Bio - Sludge & 0.305 & 0.411 \\
\hline S-9 & Combine Stored Sludge & 0.026 & 0.04 \\
\hline W-1 & Clay filter (used) & 0.622 & 0.989 \\
\hline W-2 & Thermal Insulation (used) & 0.471 & 0.667 \\
\hline W-3 & Hydrocracker Catalyst (used) & 0.02 & 0.039 \\
\hline W-4 & Ceramic Balls (used) & 0.863 & $\underline{1.045}$ \\
\hline W-5 & Clay filter (fresh) & 0.637 & 0.943 \\
\hline W-6 & Catalyst (fresh) & $\mathrm{UE}$ & UE \\
\hline Wa-1 & Water associated crude oil & 0.083 & 0.104 \\
\hline Wa-2 & Refinery Sour water & 0.046 & 0.092 \\
\hline Wa-3 & Stripped water & 0.067 & 0.115 \\
\hline Wa-4 & Oily water & 0.111 & 0.202 \\
\hline Wa-5 & Treated water & 0.003 & 0.006 \\
\hline
\end{tabular}

*: Under estimated

\section{Conclusions}

This study included radioactivity measurements and assessments of radiation exposure indicators for crude oil and its products, sludge, non-oil wastes and produced water in complex-type of petroleum refining process in Egypt.

Arab J. Nucl. Sci. \& Applic. Vol. 51, No. 4 (2018) 
The non-oil wastes recorded the highest activities of both radium isotopes $\left({ }^{226} \mathrm{Ra}\right.$ and $\left.{ }^{228} \mathrm{Ra}\right)$ and ${ }^{40} \mathrm{~K}$ among all the other studied samples.

The maximum external absorbed dose rate was 146.871 nGy/h and it was observed in waste ceramic balls (W-4). This value exceeds UNSCEAR Guideline 55nGy/h.

It was found that the average occupational annual effective dose due to direct gamma exposure is within the international recommendations $(0.07$ $\mathrm{mSv}$ ).

In spite of the fact that the calculated indices of external hazard were less than unity, an occupational radiation hazard may be associated with storage large amount of ceramic balls (W-4), clay filters (W-1 and $\mathrm{W}-5$ ) and thermal insulation (W-2), their $\mathrm{H}_{\text {ex }}$ values are 0.863, 0.622, 0.637 and 0.471 , respectively.

Due to the higher internal hazard index $\left(\mathrm{H}_{\text {in }}\right)$ it was 1.045 for ceramic balls (W-4) and it is higher than recommended value unity. It is recommended that workers who are responsible for maintaining and repairing equipment must use safety tools to protect them from the dangers of inhaling radon gas.

Generally, the overall results revealed that the radiation levels would not pose any radiological risk occupationally or for the ambient environment.

The results obtained in this study are very important in terms of establishing indicators and standards for radiation protection in this type of crude oil refining technology.

\section{References}

1- Zielinski, R.A., Otton, J.K., Budhan, J.R. Use of isotopes to determine the age and the origin of radioactive barite at oil-field production site. $M$. $J$. Environ. Rad., 46, 271-286 (2001).

2- El-Afifi, E.M., Awwad, N.S. Characterization of the TE-NORM waste associated with oil and natural gas production in Abu Rudeis, Egypt. $J$. Environ. Rad., 82, 7-19 (2005).

3- El Afifi, E.M., Awwad, N.S., Hilal, M.A. Sequential chemical treatment of radium species in TENORM waste sludge produced from oil and natural gas production. J. Haz. Mat., 161, 907-912 (2009).

4- Somlai, J., Jobba'gy, V., Somlai, K., Kova' cs, J., Ne'meth, Cs., Kova' cs, T. Connection between radon emanation and some structural properties of coal-slag as building material. Rad. Meas., 43, 7276 (2008).
5- EEP 255 (Environmental Ecological Protection) Pollution Prevention Case Study on Petroleum Refining. Eileen O. van Ravenswaay Michigan State University (Adapted from US. EPA, Profile of the Petroleum Refining Industry, September 1995. U.S. Government Printing Office, Washington,

D.C.https://www.msu.edu/course/eep/255/Petroleu mP2CaseStudy.htm EPA 310-R-95 013 (1995).

6- API (American Petroleum Institute) Bulletin on Management of Naturally Occurring Radioactive Materials (NORM) in Oil and Gas Production, first ed. API Bulletin E2 (BULE2) (1992).

7- Baird, R.D., Merrell, G.B., Klein, R.B., Rogers, V.C., Nielson, K.K. Management and Disposal Alternation for Norm Wastes in Oil Production and Gas Plant Equipment. American Petroleum Institute. 1-1-5-18 (1996).

8- IAEA (International Atomic Energy Agency) Radiation and Waste Safety in the Oil and Gas Industry. IAEA-Safety Report No. 34 (2004).

9- Jonkers, G., Hartog, F.A., Knaepen, W.A.I., Lancee, P.F.J. Characterization of NORM in the oil and gas production (E\&P) industry. In: Proceedings of the International Symposium on Radiological Problems with Natural Radioactivity in the NonNuclear Industry. Amsterdam, September 8-10, pp. 23-47 (1997).

10- Shawky, S., Amer, H., Nada, A.A., Abd ElMaksoud, T.R., Ibrahim, N.M. Characteristics of NORM in the oil industry from eastern and western desert of Egypt. Appl. Rad., Null. 55, 133-135 (2001).

11- NRPA (Norwegian Radiation Protection Authority) Natural Radioactivity in Produced Water from the Norwegian Oil and Gas Industry in 2003. Report 005:2 (2004).

12- Swann, C., Matthews, J., Ericksen, R., Kuszmaul, J. Evaluation of Radionuclides of Uranium, Thorium and Radium Associated with Produced Fluids, Precipitates and Sludges from Oil, Gas and Oilfields Brine Injections Wells in Mississippi. US Department of Energy. DE-FG26-02NT 15227 (2004).

13- Abdel-Halim, A. A., Saleh, I. H. Radiological characterization of beach sediments along the Alexandria-Rosetta coasts of Egypt. J. of Taibah University for Science, 10, 212-220 (2016).

14- Saleh, I. H., Abdel-Halim, A. A. Determination of depleted uranium using a high-resolution gammaray spectrometer and its applications in soil and sediments. J. of Taibah University for Science, 10, 205-211 (2016).

15- Nafaa Reguigui. Gamma Ray Spectrometry, Practical Information (2006).

16- El-Tahawy, M.S., Farouk, M.A., Hammad, F.H., Ibrahiem, N.M. Natural potassium as a standard 
source for the absolute efficiency calibration of $\mathrm{Ge}$ detectors, Nucl. Sci., 29, 361-363 (1992).

17- IAEA (International Atomic Energy Agency) Measurement of Radionuclides in Food and the Environment. Technical Report Series No.295, Vienna, 1989 (1989).

18- Saleh, I. H., Abdel-Halim, A. A. 7Be in soil, deposited dust, atmospheric air, and it's using to infer soil erosion along Alexandria region, Egypt. J. Environ. Rad., 172, 24-29 (2017).

19- Hu, S. J., Kandaiya, S., Benoan F. Gamma activity in surveilte., Heal. Phys., 52 (3), 379-380 (1987).

20- Beretka, J., Mathew, P.J. Natural radioactivity in Australian building materials, industrial waste and by-product. Heal. Phys., 48, 87-95 (1985).

21- NEA (Nuclear Energy Agency) Exposure to Radiation from Natural Radioactivity in Building Materials. Report by NEA Group of Experts. OECD, Paris, France (1979).

22- UNSCEAR (United Nations Scientific Committee on the Effects of Atomic Radiation) (2000) Sources, Effects and Risks of Ionization Radiation. Report to the General assembly with scientific annexes, New York, United Nations.

23- IAEA (International Atomic Energy Agency) Radiation Protection and the Management of Radioactive Waste in the Oil and Gas Industry, A guide Book, International Atomic Energy Agency, Safety reports series, No.34 (2003).

24- Deng, W., Tian, K., Zhang, Y., Chen, D. Radioactivity in Zircon and Building Tiles., Heal. Phys., 73, 2 (1997).

25- OECD (Organization for Economic Co-operation and Development) Exposure to radiation from the natural radioactivity in building materials, Report No. 1556 (1979).

26- EU (European Commission) Radiological Protection Principles concerning the Natural Radioactivity of Building Materials, Radiation protection 112 (1999).

27- Isinkaye M., Omoniyi, Shitta M. B., Oludare Oderinde M., Oluwaseyi. Determination of radionuclides and elemental composition of clay soils by gamma- and $\mathrm{X}$ ray spectrometry, Isinkaye Springer Plus, 2-74 (2013).

28- Eisenbud M. Environ. Rad., Academic Press, Orlando, USA (1987).

29- Eisenbud, M., Gesell, T. Environmental Radioactivity from Natural, Industrial, and Military Sources, fourth edition, Academic Press, San Diego (1997).

30- Rajaretnam, G., Spitz, H.B. Effect of leachability on environmental risk assessment for naturally occurring radioactive materials in petroleum oil fields. Heal. Phys., 78 (2), 191-198 (2000).

31- Slunga, E. Radon classification of building ground. Radiat. Prot. Dosim., 24 (1-4), 39-42 (1988).

32- Zarie, K.A., Al Mugren, K.S. Measurement of natural radioactivity and assessment of radiation hazard in soil samples from Tayma area (KSA). Isot. Rad. Res., 42 (1), 1-9 (2010).

33- UNSCEAR (United Nations Scientific Committee on the Effects of Atomic Radiation) Exposure of the population in the United States and Canada from natural background radiation and NCRP report no.94. National Council on Radiation Protection and Measurement, Bethesda, Maryland (1994). 